\title{
Correction
}

\section{Correction to: Utilization of geopolymer cements as supercapacitors: influence of the hardeners on their properties}

\author{
Martin Pengou ${ }^{1,2}$ (D) $\cdot$ Bertrand Ngouné ${ }^{~} \cdot$ Hervé K. Tchakouté ${ }^{1}$ Charles P. N. Nanseu ${ }^{1}$ Emmanuel Ngameni ${ }^{1}$
}

Published online: 17 July 2020

(c) Springer Nature Switzerland AG 2020

\section{Correction to: SN Applied Sciences (2020) 2:1138 \\ https://doi.org/10.1007/s42452-020-2939-1}

Figure 7 was omitted from the initial online publication.

The original article has been corrected.

Publisher's Note Springer Nature remains neutral with regard to jurisdictional claims in published maps and institutional affiliations.

The original article can be found online at https://doi.org/10.1007/s42452-020-2939-1.

$\triangle$ Martin Pengou, mapesu@yahoo.fr | 'Laboratory of Analytical Chemistry, Faculty of Science, University of Yaounde I, 812, Yaoundé, Cameroon. ${ }^{2}$ Department of Chemistry, Faculty of Science, University of Maroua, Maroua, Cameroon. 